\title{
Peningkatan Kemampuan Penalaran Matematis Siswa Melalui Problem Posing Ditinjau Dari Tahap Perkembangan Kognitif Siswa
}

\author{
Oom Romsih * \\ Magister Pendidikan Matematika Pascasarjana Universitas Sultan Ageng Tirtayasa, Banten, Indonesia, \\ *Penulis Korespondensi, oomromsih@gmail.com \\ Yuyu Yuhana \\ Magister Pendidikan Matematika Pascasarjana Universitas Sultan Ageng Tirtayasa, Banten, Indonesia, \\ yuhana965@gmail.com

\section{Hepsi Nindiasari} \\ Magister Pendidikan Matematika Pascasarjana Universitas Sultan Ageng Tirtayasa, Banten, Indonesia, \\ hepsinindiasari@yahoo.co.id
}

\begin{tabular}{|c|c|}
\hline Informasi Artikel & ABSTRAK \\
\hline Sejarah artikel: & $\begin{array}{l}\text { Penelitian ini bertujuan untuk melihat pengaruh penggunaan } \\
\text { pendekatan pembelajaran problem posing dalam meningkatkan }\end{array}$ \\
\hline Diterima 15 Oktober 2018 & kemampuan penalaran matematis siswa ditinjau dari tahap \\
\hline Direvisi 20 Oktober 2018 & perkembangan kognitif siswa. Penelitian ini menggunakan \\
\hline Disetujui 09 November 2018 & metode quasi eksperimen dengan dua kelas yang dijadikan \\
\hline \multirow{9}{*}{$\begin{array}{l}\text { Kata kunci: } \\
\text { Problem Posing, Kemampuan } \\
\text { Penalaran Matematis, Tahap } \\
\text { Perkembangan Kognitif }\end{array}$} & tahap perkembangan kognitif siswa diperoleh melalui tes \\
\hline & kemampuan penalaran matematis dan Tes Of Logical Thinking \\
\hline & (TOLT). Data yang dihasilkan dianalisis untuk dilihat \\
\hline & perbedaan rerata dari ketiga tahap kognitif pada kelas yang \\
\hline & bahwa pada tahap perkembangan kognitif formal tidak \\
\hline & $\begin{array}{l}\text { terdapat perbedaan rerata kemampuan penalaran matematis, } \\
\text { sedangkan pada tahap perkembangan kognitif transisi dan }\end{array}$ \\
\hline & $\begin{array}{l}\text { konkret menunjukkan terdapat perbedaan rerata penalaran } \\
\text { matematis antara siswa yang menggunakan pendekatan } \\
\text { problem posing dengan siswa yang menggunakan pendekatan } \\
\text { saintifik. }\end{array}$ \\
\hline & $\begin{array}{l}\text { Copyright } \odot 2018 \text { by the authors; licensee Department of Mathematics Education, } \\
\text { University of Singaperbangsa Karawang. All rights reserved. }\end{array}$ \\
\hline & $\begin{array}{l}\text { This is an open access article distributed under the terms of the CC BY-SA license. } \\
\text { (http://creativecommons.org/licenses/by-sa/4.0) }\end{array}$ \\
\hline
\end{tabular}

\section{PENDAHULUAN}

Pembelajaran matematika bertujuan agar siswa memiliki kecakapan atau kemahiran matematika yang merupakan bagian dari kecakapan hidup yang harus dimiliki peserta didik terutama dalam pengembangan penalaran, komunikasi, dan pemecahan masalah (problem solving) yang dihadapi dalam kehidupan sehari-hari.

Menghadapi era globalisasi dan perkembangan teknologi yang semakin canggih, pendidikan nasional Indonesia perlu meningkatkan mutu dan kualitas pembelajaran sehingga hasil pendidikan yang dilaksanakan memiliki lulusan yang mampu bersaing di tingkat Internasional (mendunia). Namun hingga saat ini, pendidikan yang dilaksanakan di Indonesia belum menunjukkan hasil yang memuaskan. Masalah lain yang ditemui dalam 
pendidikan matematika di sekolah adalah bahwa pendekatan dalam pembelajaran masih terlalu didominasi peran guru (teacher center). Guru banyak menempatkan siswa sebagai obyek dan bukan sebagai subyek didik, walaupun kurikulum 2013 telah mengkondisikan agar proses pembelajaran mengarahkan siswa untuk aktif dalam mengkonstruksi pengetahuan yang dipelajarinya.

Baroody dalam (Bernard \& Rohaeti, 2016) mengemukakan bahwa membangun kompetensi penalaran matematik sangat penting untuk membantu siswa tidak sekedar mengingat fakta, aturan, dan langkah-langkah, tetapi menggunakan keterampilan bernalarnya dalam melakukan pendugaan atas dasar pengalamannya sehingga siswa akan memperoleh pemahaman konsep matematik secara bermakna (meaningfull learning).

Kemampuan penalaran merupakan kemampuan berpikir tingkat tinggi dalam pembelajaran matematika. Penalaran matematika dan pembelajaran matematika merupakan dua hal yang saling berkaitan dan tidak dapat dipisahkan, karena materi matematika dipahami melalui penalaran dan penalaran dapat dipahami dan dilatihkan melalui belajar matematika.

Perkembangan kognitif merupakan salah satu penentu keberhasilan dalam kurikulum pendidikan matematika. Pentingnya tahap perkembangan kognitif dalam pendidikan berkaitan dengan kemampuan persepsi siswa, ingatan siswa, asosiasi, penalaran dan pemecahan masalah. Menurut Piaget, proses belajar seseorang akan mengikuti pola dan tahap perkembangan sesuai dengan umurnya. UsiaSMP menunjukkan bahwa pada usia tersebut siswa berada pada fase kongkret-formal. Pada tahap perkembangan ini, siswa mulai berpikir abstrak dan logis, dengan karakteristik siswa yaitu bekerja secara efektif dan sistematis, menganalisis secara kombinasi, berpikir secara proporsional, dan menarik kesimpulan secara generalisasi (Putra, 2014).

Tahap perkembangan kognitif menunjukkan tahap perkembangan kemampuan siswa dalam menyelesaikan masalah. Siswa yang mempunyai tingkat perkembangan kognitif lebih tinggi, dapat menyelesaikan masalah yang memerlukan kemampuan proses logis yang bervariasi, yang tidak dimiliki pada tingkat perkembangan kognitif di bawahnya (Santosa, 2013). Pendapat tersebut juga senada dengan Piaget dalam Sumarmo (1987) yang mengungkapkan bahwa subyek formal memiliki kemampuan yang lebih tinggi daripada subyek konkret. Pandangan ini mengartikan bahwa siswa formal lebih tinggi kemampuannya daripada siswa konkret dalam kondisi apapun (Nindiasari, 2004).

Pendekatan problem posing adalah suatu pendekatan pembelajaran yang aktif dan kreatif. Siswa diminta untuk membuat soal/permasalahan berdasarkan situasi/kondisi yang telah disiapkan oleh guru untuk kemudian secara bersama-sama atau individu menyelesaikan soal atau permasalahannya sendiri. Pada kegiatan pembelajaran di kelas, dengan kondisi tahap perkembangan kognitif siswa yang berbeda-beda, dituntut peran guru untuk dapat mengembangkan kemampuan berpikir siswa sesuai dengan tahap perkembangan kognitif masing-masing. Melalui kegiatan problem posing /pengajuan masalah diharapkan dapat mengembangkan kemampuan berpikir matematis siswa.

Tahap perkembangan kognitif yang berbeda, akan berdampak pada kemampuan dalam membuat ide soal/masalah dari masing-masing siswa. Menurut Piaget dalam Suparno (2001), kemampuan berpikir abstrak siswa yang berada pada tahap perkembangan kognitif formal, secara teoritis lebih tinggi daripada kemampuan siswa yang berada pada tahap perkembangan kognitif kongkret. Memahami kondisi tahap perkembangan siswa perlu dilakukan untuk dapat memilih strategi pembelajaran yang digunakan sehingga dapat merangsang kemampuan matematika siswa. 


\section{METODE}

Metode penelitian yang digunakan adalah quasi eksperimen yang bertujuan untuk mengungkapkan hubungan sebab akibat dengan cara melibatkan kelompok kontrol disamping kelompok eksperimen. Penelitian eksperimental semu/quasi eksperimen bertujuan untuk menjelaskan hubungan-hubungan,mengklarifikasi penyebab terjadinya suatu peristiwa, atau keduanya (Sugiyono, 2017). Desain Penelitian yang digunakan adalah pretest-posttest control group yang digambarkan sebagai berikut:

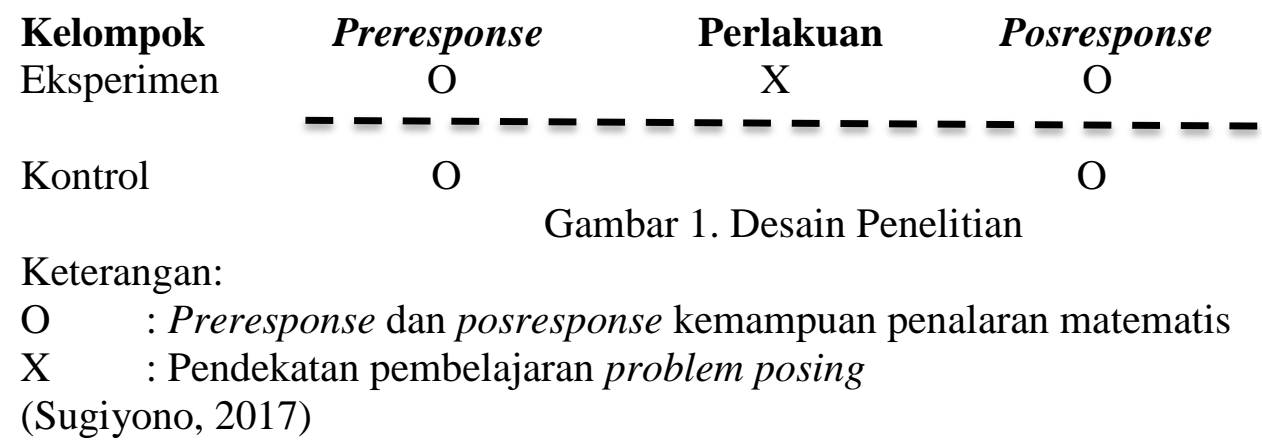

Populasi dalam penelitian ini adalah seluruh siswa kelas VIII semester genap salah satu SMP Negeri di Kota Serang Tahun ajaran 2017/2018 yang terdiri dari 8 kelas dengan jumlah siswa 288 orang. Sampel penelitian terdiri dari dua kelas yang diberi perlakuan yang berbeda, yaitu kelas VIII D melaksanakan pembelajaran dengan menggunakan pendekatan problem posing sedamgkan kelas VIII H menggunakan pendekatan saintifik.

Kegiatan penelitian diawali dengan melaksanakan tes untuk mengukur tahap perkembangan kognitif siswa dengan menggunakan instrumen TOLT (Test Of Logical Thinking) yang digunakan oleh Capie dan Tobin (Sumarmo, 1987). Hasil tes TOLT digunakan untuk melakukan penempatan kelompok sampel penelitian pada tahap perkembangan kognitif konkret, transisi, dan formal.

Data kemampuan penalaran matematis diambil dengan menggunakan soal tes kemampuan penalaran matematis yang dibuat dalam bentuk uraian terdiri dari 6 butir soal yang disesuaikan dengan banyaknya indikator penalaran matematis. Tes kemampuan penalaran matematis dilaksanakan sebelum dan sesudah melaksanakan kegiatan pembelajaran pada kelas eksperimen maupun kelas kontrol.

Teknik analisis data yang digunakan adalah:

1) Analisis data dengan statistik deskriptif yaitu berupa penyajian data dalam bentuk tabel distribusi frekuensi, histogram, diagram garis atau diagram lingkaran.

2) Menguji peningkatan kemampuan penalaran matematis siswa dengan menggunakan rumus $\mathrm{N}$-gain Hake (Meltzer, 2002) antara sebelum dan setelah perlakuan .

Rumus $N$-Gain $=\frac{\text { Skor postes-Skor pretes }}{\text { SMI-Skor pretes }}$,

SMI = Skor Maksimum Ideal

3) Analisis data dengan statistik inferensial sesuai dengan hipotesis penelitian yang telah ditentukan adalah analisis data uji statistik parametrik dan non parametrik. Penentuan jenis uji statistik tersebut tergantung kepada jenis data yang dianalisis apakah berdistribusi normal atau tidak.

Uji statistik yang dilaksanakan adalah menguji beda rerata pada kelompok kognitif konkret, transisi, dan formal antara kelas yang menggunakan pendekatan problem posing dan kelas yang menggunakan pendekatan saintifik. 


\section{HASIL DAN PEMBAHASAN}

\section{Hasil}

Pada awal penelitian, terhadap kedua kelompok sampel diberikan tes penalaran matematis dan tes tahapan kognitif (TOLT) untuk melihat level tahapan kognitif dan kemampuan awal penalaran matematis siswa. Setelah dilaksanakan perlakuan selama dua bulan, siswa mengikuti tes akhir kemampuan penalaran matematis dengan jenis instrumen yang sama.

Hasil tes tahapan kognitif dan kemampuan penalaran matematis siswa disajikan pada Tabel berikut ini:

Tabel 1. Data Tahap Kognitif Formal dan Kemampuan Penalaran Matematis

\begin{tabular}{clcccccc}
\hline $\begin{array}{c}\text { Tahap } \\
\text { Kognitif }\end{array}$ & Data & \multicolumn{3}{c}{ Problem Posing } & \multicolumn{3}{c}{ Saintifik } \\
& & Pretes & Postes & $N$-gain & Pretes & Postes & $N$-gain \\
\hline \multirow{5}{*}{ Formal } & N & & 9 & & & 5 & \\
& Min & 25,00 & 63,00 & 0,14 & 17,00 & 46,00 & 0,28 \\
& Max & 71,00 & 83,00 & 0,71 & 42,00 & 75,00 & 060 \\
& $\overline{\boldsymbol{x}}$ & 42,56 & 73,67 & 0,52 & 24,40 & 62,80 & 0,51 \\
& SD & 16,69 & 6,32 & 0,16 & 10,38 & 10,59 & 0,13 \\
& & & & & & & \\
\hline
\end{tabular}

Tabel 2. Data Tahap Kognitif Transisi dan Kemampuan Penalaran Matematis

\begin{tabular}{clcccccc}
\hline $\begin{array}{c}\text { Tahap } \\
\text { Kognitif }\end{array}$ & Data & \multicolumn{2}{c}{ Problem Posing } & & Saintifik \\
& & Pretes & Postes & $\boldsymbol{N}$-gain & Pretes & Postes & $\boldsymbol{N}$-gain \\
\hline & N & & 20 & & & 21 & \\
& Min & 17,00 & 46,00 & 0,25 & 4,00 & 25,00 & 0,05 \\
Transisi & Max & 67,00 & 88,00 & 0,70 & 54,00 & 71,00 & 0,63 \\
& $\bar{x}$ & 41,85 & 69,70 & 0,48 & 26,52 & 56,24 & 0,39 \\
& SD & 12,16 & 10,74 & 0,13 & 12,60 & 11,47 & 0,16 \\
& & & & & & & \\
\hline
\end{tabular}

Tabel 3. Data Tahap Kognitif Konkret dan Kemampuan Penalaran Matematis

\begin{tabular}{clcccccc}
\hline $\begin{array}{c}\text { Tahap } \\
\text { Kognitif }\end{array}$ & Data & \multicolumn{2}{c}{ Problem Posing } & \multicolumn{3}{c}{ Saintifik } \\
& & Pretes & Postes & $\boldsymbol{N}$-gain & Pretes & Postes & $\boldsymbol{N}$-gain \\
\hline \multirow{3}{*}{ Konkret } & N & & 9 & & & 10 & \\
& Min & 13,00 & 58,00 & 0,29 & 13,00 & 29,00 & 0,18 \\
& Max & 42,00 & 79,00 & 0,71 & 33,00 & 67,00 & 0,62 \\
& $\overline{\boldsymbol{x}}$ & 29,44 & 70,00 & 0,56 & 22,20 & 53,00 & 0,39 \\
& SD & 10,87 & 6,78 & 0,14 & 8,44 & 14,47 & 0,18 \\
& & & & & & & \\
\hline
\end{tabular}

Berdasarkan Tabel 1, 2, dan 3, terlihat bahwa terdapat perbedaan rerata kemampuan penalaran matematis pada setiap kelompok tahapan kognitif konkret, transisi, maupun 
formal antara kelas yang menggunakan pendekatan problem posing dengan kelas yang menggunakan pendekatan saintifik. Pembuktian secara statistik perbedaan rerata dilaksanakan dengan menggunakan aplikasi tertentu yang merujuk pada hipotesis statistik yang digunakan. Hipotesis yang digunakan dalam penelitian ini adalah:

$\mathrm{H}_{0}$ : rerata pretes/postes/N-gain kelas yang menggunakan pendekatan problem posing sama dengan rerata kelas yang menggunakan pendekatan saintifik pada tahap kognitif konkret, transisi, dan formal

$\mathrm{H}_{1}$ : rerata pretes/postes/N-gain kelas yang menggunakan pendekatan problem posing berbeda dengan rerata kelas yang menggunakan pendekatan saintifik pada tahap kognitif konkret, transisi, dan formal.

Sebelum melakukan uji statistik terhadap data kemampuan penalaran matematis, terlebih dahulu dilakukan uji normalitas dan homogenitas data sebagai syarat dalam menentukan langkah pengujian selanjutnya. Jika data berdistribusi normal dan homogen, maka dilakukan uji statistik parametrik, sedangkan jika data berdistribusi tidak normal maka dilakukan uji statistik non parametrik. Hasil uji statistik beda rerata untuk pretes, postes, dan $\mathrm{N}$-gain dari ketiga kelompok tahapan kognitif ditunjukkan pada tabel berikut ini:

Tabel 4. Uji Beda Dua Rerata Pretes Kemampuan Penalaran Matematis Berdasarkan Tahap Kognitif Siswa

\begin{tabular}{lcccc}
\hline Tahap & \multicolumn{3}{c}{ Statistik } & \multirow{2}{*}{ Keterangan } \\
Kognitif & $\mathrm{t}$ & $\mathrm{Df}$ & Sig-2 tailed & \\
\hline Formal & 2,186 & 12 & 0,049 & $\mathrm{H}_{0}$ ditolak \\
Transisi & 3,960 & 39 & 0,000 & $\mathrm{H}_{0}$ ditolak \\
& Mann-Whitney $U$ & $\mathrm{Z}$ & $\begin{array}{c}\text { Asymp.Sig } \\
(2 \text { tailed })\end{array}$ & \\
& & $-1,525$ & 0,127 & $\mathrm{H}_{0}$ diterima \\
\hline
\end{tabular}

Tabel 5. Uji Beda Dua Rerata Postes Kemampuan Penalaran Matematis Berdasarkan Tahap Kognitif Siswa

\begin{tabular}{lcccc}
\hline Tahap & & Statistik & Keterangan \\
Kognitif & $\mathrm{t}$ & $\mathrm{Df}$ & Sig-2 tailed & \\
\hline Formal & 2,434 & 12 & 0,032 & $\mathrm{H}_{0}$ ditolak \\
Transisi & 3,874 & 39 & 0,000 & $\mathrm{H}_{0}$ ditolak \\
Konkret & 3,331 & 13,056 & 0,005 & $\mathrm{H}_{0}$ ditolak \\
\hline
\end{tabular}

Tabel 6. Uji Beda Rerata $N$-gain Kemampuan Penalaran Matematis Siswa berdasarkan Tahap Perkembangan Kognitif Siswa

\begin{tabular}{|c|c|c|c|c|}
\hline \multirow{2}{*}{$\begin{array}{l}\text { Tahap } \\
\text { Kognitif }\end{array}$} & \multicolumn{3}{|c|}{ Statistik } & \multirow[b]{2}{*}{ Keterangan } \\
\hline & Mann-Whitney $U$ & Z & $\begin{array}{c}\text { Asymp.Sig } \\
\text { (2 tailed) }\end{array}$ & \\
\hline Formal & 22,000 & $-0,067$ & 0,947 & $\mathrm{H}_{0}$ diterima \\
\hline Konkret & $\begin{array}{c}16,500 \\
\mathrm{t}\end{array}$ & $\begin{array}{c}-2,331 \\
\text { Df }\end{array}$ & $\begin{array}{c}0,020 \\
\text { Sig-2 tailed }\end{array}$ & $\mathrm{H}_{0}$ ditolak \\
\hline Transisi & 1,878 & 39 & 0,068 & $\mathrm{H}_{0}$ ditolak \\
\hline
\end{tabular}




\section{Pembahasan}

Pelaksanaan Tes Of Logical Thinking (TOLT) pada kelas yang menggunakan pendekatan problem posing menunjukkan bahwa kelompok kognitif formal berada dikisaran 23,7\% dari jumlah siswa, kelompok kognitif transisi berada pada kisaran 52,6\% dan kelompok kognitif konkret berada di kisaran 23,7\%. Ini berarti sebagian besar siswa pada kelas yang menggunakan pendekatan problem posing berada pada tahap perkembangan kognitit transisi.

Pada kelas yang menggunakan pendekatan saintifik menunjukkan bahwa kelompok kognitif formal berada di kisaran 13,9\% dari jumlah siswa, kelompok kognitif transisi berada pada kisaran 58,3\% dan kelompok kognitif konkret berada di kisaran 27,8\%. Seperti hal pada kelompok siswa yang menggunakan pendekatan problem posing, ternyata sebagian siswa besar siswa berada pada kelompok kognitif transisi.

Hal ini sejalan dengan teori belajar yang dikemukan oleh Piaget bahwa setiap anak memiliki urutan tahap perkembangan kognitif yang sama/tetap, akan tetapi usia kronologis memasuki setiap tahap berbeda-beda. Hal inilah yang menyebabkan pada setiap kelompok sampel terdapat siswa yang berada pada tahap kognitif konkret, transisi, dan formal.

Pada kelompok siswa yang menggunakan pendekatan problem posing menunjukkan bahwa rata-rata kelompok kognitif formal lebih tinggi jika dibandingkan dengan rata-rata dari kelompok kognitif transisi ataupun konkret. Demikian juga untuk kelompok kelas yang menggunakan pendekatan saintifik terlihat bahwa rata-rata kelompok kognitif formal lebih tinggi jika dibandingkan dengan rata-rata siswa pada tahap kognitif transisi ataupun konkret.

Data penelitian yang diperoleh sejalan dengan pendapat yang dikemukan oleh Piaget (Suparno, 2001) yang menyatakan bahwa pada usia 11-12 tahun ke atas anak berada pada tahapan formal dengan kemampuan pada tahap ini, seorang anak sudah dapat berpikir logis, berpikir dengan pemikiran teoritis formal berdasarkan proposisi-proposisi dan hipotesis, dan dapat mengambil kesimpulan lepas dari apa yang dapat diamati saat itu. Cara berpikir yang abstrak mulai dimengerti, sehingga pada saat ketiga kelompok tahapan kognitif ini diberikan tes yang sama menunjukkan bahwa hasil tes kemampuan penalaran matematis pada kelompok kognitif formal lebih tinggi dibandingkan hasil tes kemampuan penalaran matematis pada kelompok transisi ataupun konkret.

Pada kelompok kognitif formal, anak sudah dapat menyelesaikan soal tes penalaran yang mengacu pada indikator butir soal menggunakan pola dan hubungan untuk menganalisis atau membuat generalisasi. Pada indikator ini, siswa diminta untuk menganalisa sebuah gambar agar dapat melihat keterkaitan dan pola yang berlaku antara gambar yang satu dengan gambar yang lain hingga pada akhirnya siswa menarik kesimpulan yang berlaku secara umum berdasarkan gambar yang disajikan. Pada teori yang dikemukan oleh Piaget, situasi ini disebut sebagai pemikiran induktif Saintifik.

Pengelompokkan siswa berdasarkan tahap perkembangan kognitif merupakan salah satu strategi dalam memilih metode ataupun pendekatan pembelajaran yang digunakan sesuai dengan situasi yang dihadapi. Penggunakan pendekatan problem posing dianggap sesuai dengan penggolongan tahap kognitif. Mengetahui posisi/tahap kognitif yang dimiliki siswa akan berdampak pada pemahaman seorang guru terhadap kemampuan berpikir dari siswa tersebut yang akan terwujud dalam proses pengajuan masalah yang dibuat siswa.

Problem posing adalah suatu kegiatan yang sangat penting dalam pembelajaran matematika. Pentingnya kegiatan problem posing ini diungkapkan oleh Kilpatrick (Bonotto, 2013) yang mengemukakan bahwa problem posing merupakan konten yang 
esensial dalam matematika dan hakekat berpikir matematik, serta merupakan bagian penting dalam penyelesaian masalah.

Rasional tentang pentingnya problem posing juga tertuang dalam NCTM (2000) yang menyarankan bahwa siswa harus dilatih untuk merumuskan masalah atau pertanyaan berdasarkan situasi yang disajikan baik di dalam ataupun di luar matematika. Siswa juga disarankan agar diberi kesempatan menyusun sendiri masalah atau pertanyaan, menemukan konjektur, serta menggeneralisasi serta memperluas masalah dengan cara menyusun pertanyaan berikutnya dari pertanyaan yang sudah ada dan kemudian menyelesaikan masalah yang diajukannya.

Proses kegiatan problem posing yang dilaksanakan pada penelitian kali ini adalah siswa diminta untuk menyusun soal/masalah berdasarkan situasi atau masalah yang disajikan oleh guru untuk kemudian menyelesaikan masalah/soal buatannya secara berkelompok. Saat siswa melaksanakan kegiatan problem posing, siswa pada kelompok kognitif formal mampu menyusun soal yang lebih rumit serta permasalahan yang lebih kompleks dibandingkan dengan siswa pada kelompok kognitif konkret. Kualitas soal atau masalah yang dibuat menunjukkan kemampuan berpikir seorang siswa (Sumarmo, 2015).

Perbedaan kualitas soal buatan seorang siswa cenderung berelasi dengan kemampuan matematika siswa itu sendiri. Anak yang memiliki kemampuan matematika yang cukup baik, akan membuat soat/masalah yang menantang yang pada penyelesaian masalah/soalnya nanti memerlukan pengkaitan dengan materi-materi lain yang relevan dengan soal tersebut.

Hasil uji statistik beda rerata pretes pada masing- masing kelompok tahapan kognitif menunjukkan bahwa pada kelompok kognitif formal yang memiliki nilai sig $=0,049 / 2=$ $0,0295<0,05$. Ini menunjukkan bahwa terdapat perbedaan rerata nilai pretes kemampuan penalaran matematis pada kelompok kognitif formal antara siswa yang menggunakan pendekatan problem posing dengan siswa yang menggunakan pendekatan saintifik. Hal ini berarti sejak awal kemampuan penalaran matematis kelompok kognitif formal telah memiliki perbedaan antara siswa yang menggunakan pendekatan pembelajaran problem posing dengan siswa yang menggunakan pendekatan saintifik.

Hasil uji statistik beda rerata pretes pada kelompok kognitif transisi menunjukkan nilai sig $=0,000<0,05$. Secara teori jika nilai sig $<0,05$ berarti terdapat perbedaan rerata nilai pretes kemampuan penalaran matematis antara kelompok siswa yang menggunakan pendekatan problem posing dengan siswa yang menggunakan pendekatan saintifik. Pada kelompok kognitif konkret menunjukkan nilai sig $=0,127 / 2=0,064>0,05$. Ini berarti tidak terdapat perbedaan rerata pada kelompok kognitif konkret antara siswa yang menggunakan pendekatan problem posing dengan siswa yang menggunakan pendekatan saintifik.

Kegiatan penilaian kemampuan penalaran matematis di akhir penelitian (postes) dilaksanakan dengan menggunakan instrumen penalaran yang sama dengan instrumen yang digunakan pada saat pretes. Data hasil postes diuji dengan menggunakan analisis uji beda rerata antara siswa yang menggunakan pembelajaran problem posing dengan siswa yang menggunakan pembelajaran saintifik pada masing-masing tahapan kognitif. Hasil analisis data menunjukkan bahwa pada tahap perkembangan kognitif formal nilai sig yang diperoleh adalah $0,032 / 2=0,016<0,05$. Ini berarti terdapat perbedaan rerata postes kemampuan penalaran matematis antara siswa yang menggunakan pendekatan problem posing dengan siswa yang menggunakan pendekatan saintifik.

Pada tahap perkembangan kognitif transisi nilai sig $=0,000<0,05$; ini berarti bahwa terdapat perbedaan rerata postes kemampuan penalaran matematis antara siswa yang menggunakan pendekatan problem posing dengan siswa yang menggunakan pendekatan 
saintifik. Demikian hal nya pada kelompok kognitif konkret dengan nilai sig $=0,005<$ 0,05 . Ini berarti bahwa terdapat perbedaan rerata postes kemampuan penalaran matematis antara siswa yang menggunakan pendekatan problem posing dengan siswa yang menggunakan pendekatan saintifik pada tahap perkembangan kognitif konkret.

Berdasarkan analisis data nilai pretes dan postes kemampuan penalaran matematis terlihat bahwa di awal maupun akhir penelitian terdapat perbedaan rerata antara siswa yang menggunakan pendekatan problem posing dengan siswa yang menggunakan pendekatan saintifik. Untuk melihat sejauh mana pengaruh kegiatan pembelajaran problem posing terhadap kemampuan penalaran matematis siswa antara sebelum dan sesudah penelitian maka dilakukan uji beda rerata $\mathrm{N}$-gain antara siswa yang menggunakan pendekatan problem posing dengan siswa yang menggunakan pendekatan saintifik.

Hasil analisis data untuk melihat beda rerata $N$-gain dari masing-masing kelompok tahapan kognitif menunjukkan bahwa kelompok kognitif formal memiliki nilai sig $=0,947$ $12=0,474>0,05$ yang berarti tidak terdapat perbedaan rerata $\mathrm{N}$-gain antara antara siswa yang menggunakan pendekatan problem posing dengan siswa yang menggunakan pendekatan saintifik. Pada tahapan kognitif transisi menunjukkan bahwa nilai sig $=0,020 / 2=0,010<0,05$; ini berarti bahwa terdapat perbedaan rerata antara siswa yang menggunakan pendekatan problem posing dengan siswa yang menggunakan pendekatan saintifik, sedangkan pada tahap kognitif konkret nilai sig $=0,068 / 2=0,034<0,05$; ini berarti bahwa terdapat perbedaan rerata antara siswa yang menggunakan pendekatan problem posing dengan siswa yang menggunakan pendekatan saintifik.

Berdasarkan penyajian data secara deskriptif ataupun analisis data dengan pengujian beda rerata masing-masing kelompok menunjukkan bahwa pada kelompok kognitif formal tidak terdapat perbedaan rerata, sedangkan pada tahapan kognitif transisi dan konkret terdapat perbedaan rerata kemampuan penalaran matematis antara siswa yang menggunakan pendekatan problem posing dengan siswa yang menggunakan pendekatan saintifik.

Pada kelompok formal, kemampuan matematika siswa lebih tinggi jika dibandingkan denga kelompok transisi ataupun konkret, sehingga pada kelompok ini strategi pembelajaran yang digunakan tidak terlalu berpengaruh terhadap kemampuan penalaran matematis siswa.

Hal ini sejalan dengan pendapat yang diungkapkan oleh Piaget dalam (Suparno, 2001) yang menyatakan bahwa tahap-tahap perkembangan anak saling berkaitan, tidak dapat ditukar atau dibalik. Perbedaan antar tahap sangat besar karena ada perbedaan kualitas pemikiran. Tahap perkembangan kognitif formal merupakan tahap perkembangan yang tertinggi yang memiliki ciri-ciri perkembangan hipotetis, abstrak, deduktif dan induktif, logis dan probabilitas. Berdasarkan ciri perkembangan tersebut maka anak pada tahap formal telah mampu memahami materi yang bersifat abstrak tanpa bantuan benda atau peristiwa konkret.

\section{SIMPULAN}

Berdasarkan hasil penelitian dan pembahasan yang telah dipaparkan, maka kesimpulan yang diperoleh adalah sebagai berikut:

a) Pada kelompok kognitif formal, tidak terdapat perbedaan rata-rata kemampuan penalaran matematis antara siswa yang menggunakan pendekatan problem posing dengan siswa yang menggunakan pendekatan saintifik. 
b) Terdapat perbedaan rata-rata kemampuan penalaran matematis antara siswa yang menggunakan pendekatan problem posing dengan siswa yang menggunakan pendekatan saintifik pada tahap perkembangan kognitif transisi dan konkret.

c) Problem posing merupakan salah satu pendekatan pembelajaran yang sesuai dengan tahap perkembangan kognitif siswa khususnya bagi siswa yang memiliki tahap perkembangan kognitif transisi dan konkret.

d) Problem posing mampu mengembangkan kemampuan penalaran matematis siswa ditinjau dari tahap perkembangan kognitif siswa.

\section{DAFTAR PUSTAKA}

Bernard, M., \& Rohaeti, E.(2015). Meningkatkan Kemampuan Penalaran dan Disposisi Matematik Siswa Melalui Pembelajaran Kontekstual Berbantuan Game Adobe Flash CS 4.0. Edusentris. Jurnal Ilmu Pendidikan dan Pengajaran, 3(1), 85-94.

Bonotto, C. (2010) Realistic Mathematical Modeling and Problem Posing. In: Lesh R., Galbraith P., Haines C., Hurford A. (eds) Modeling Students' Mathematical Modeling Competencies. ICMA13. Springer, Boston, MA, 399-408.

Meltzer, David. E. (2002). The relationship between mathematics preparation and conceptual learning gains in physics : A possible " hidden variable " in diagnostic pretest scores, Am. J. Phys., 70(12), 1259-1268. https://doi.org/10.1119/1.1514215.

NCTM. (2000). Principles and standards for school mathematics. Reston, VA: NCTM.

Nindiasari, H. (2004). Pembelajaran Metakognitif Untuk Meningkatkan Pemahaman dan Koneksi Matematika Siswa SMU Ditinjau dari Perkembangan Kognitif Siswa. Tesis. UPI Bandung. Tidak diterbitkan.

Putra, H.D. (2014). Tahap Perkembangan Kognitif Matematika Siswa MTs AsySyifa Kelas IX Berdasarkan Teori Piaget. Prosiding Seminar Nasional Pendidikan Matematis STKIP Siliwangi, 2, 224-230.

Santosa, H.F., \& Cecep, A. (2013). Mengukur Tingkat Pencapaian Perkembangan Kognitif Siswa SMA Menggunakan Operasi Logika Piaget. Delta-Pi: Jurnal Matematika dan Pendidikan Matematika, 2(1), 27-34.

Sugiyono. (2017). Metode Penelitian Kuantitatif, Kualitatif dan R\&D (26 th, ed. P.76-77). Alfabeta: Bandung.

Sumarmo, U. (1987). Kemampuan Pemahaman dan Penalaran Matematika Siswa Dikaitkan Dengan Kemampuan Penalaran Logika Siswa dan Beberapa Unsur Proses Belajar Mengajar. Disertasi PPs UPI Bandung. Tidak diterbitkan.

Sumarmo, U. (2015). Mathematical Problem Posing: Rasional, Pengertian, Pembelajaran dan Pengukurannya, 1-28.

Suparno, P. (2001). Teori Perkembangan Kognitif Jean Piaget. Kanisius: Yogyakarta. 


\title{
Enhancing Students' Mathematical Reasoning Skills through Problem Posing in Terms of Students' Cognitive Development Stages
}

\author{
Oom Romsih * \\ Mathematics Education Postgraduate Program, Universitas Sultan Ageng Tirtayasa, Banten, Indonesia, \\ *Corresponding Author, oomromsih@gmail.com

\section{Yuyu Yuhana} \\ Mathematics Education Postgraduate Program, Universitas Sultan Ageng Tirtayasa, Banten, Indonesia, \\ yuhana965@gmail.com

\section{Hepsi Nindiasari} \\ Mathematics Education Postgraduate Program, Universitas Sultan Ageng Tirtayasa, Banten, Indonesia, \\ hepsinindiasari@yahoo.co.id
}

\begin{abstract}
The purpose of this research was to determine the effectiveness of problem posing approach in improving students 'mathematical reasoning skills in terms of students' cognitive development stages. This research used a quasi-experimental method with two classes being used as samples of the study. Data on mathematical reasoning ability and cognitive development stages of students were obtained through tests of mathematical reasoning skills and Test of Logical Thinking (TOLT). The resulting data were analyzed to see the mean differences from the three cognitive stages in the class as the research sample. The results showed that there was no difference in the mean level of mathematical reasoning at the level of formal cognitive, while the transitional and concrete cognitive level showed that there were differences in mean mathematical reasoning between students who use the problem-posing approach with students who use the scientific approach.
\end{abstract}

Keywords: Problem posing; mathematical reasoning; cognitive development stages

Received October $15^{\text {th }}, 2018$

Revised October $20^{\text {th }}, 2018$

Accepted November $09^{\text {th }}, 2018$ 